\title{
Analisis Peraturan Gubernur Tanpa Dasar Peraturan Daerah dalam Penyelenggaraan Otonomi Daerah
}

\author{
An Analysis of Governor Regulation Without the Basis of Regional \\ Regulations in the Implementation of Regional Autonomy
}

\author{
Sumarfa \\ PT. Akmal Butur Gemilang \\ E-mail: afanfan27727@gmail.com \\ Guasman Tatawu \\ Pascasarjana Universitas Halu Oleo \\ E-mail: gtatawu@gmail.com \\ Kamaruddin Jafar \\ Pascasarjana Universitas Halu Oleo \\ E-mail: kamaruddinjafar.88@gmail.com
}

\begin{abstract}
The aim of this research is to analyzing governor regulation which is published without legal basis of regional regulations having legal legitimacy. The another aim is to analyzing the synchronization of laws governor regulation that published earlier to the regional regulations that were formed. The implementation of regional government has a condition that requires immediate handling but does not yet have local regulations as a legal basis so that meeted local government discretion with the establishment of Southeast Sulawesi Governor Regulation number 35 of 2012 about the Needs and Highest Retail Prices of Subsidized Fertilizers for the Agriculture Sector in 2013. This research is uses legal research through statute approach and conceptual law. The results of this research is the governor regulation which was published without the basis of regional regulations having limited legal legitimacy because hierarchically the Governor regulation are implementing regulation of regional regulation in the concept of regional autonomy, this is regulated in legislation number 12 of 2011 about the Formation of Statutory Regulation and Legislation number 23 of 2014 about Regional Government and relevant legal theories. That to guarantee law certainty, the validity of the law needs to be done vertically synchronizing. The Vertical synchronization with prioritizing principle of justice of Lex superior derogat legi inferior. The step of vertical synchronization is a governor regulation that has been published, which is renewed into a regional regulation after that is published a new governor regulation. synchronization of the law has the role of maintaining harmony and preventing overlapping legislation regulation. There are recommendations including the need for regulations on the mechanism of synchronizing governor regulation into regional regulations and the regional house of representatives needs to improves its
\end{abstract}


performance in the field of legislation in order to prevent the issuance of governor regulation prior to their regional regulation.

Keyword: Regional Goverment; Regional Governor; Regional Autonomy

Abstrak: Penelitian ini bertujuan untuk menganalisis peraturan gubernur yang diterbitkan tanpa dasar hukum peraturan daerah memiliki legitimasi hukum. Tujuan lainnya adalah untuk menganalisis sinkronisasi hukum peraturan gubernur yang diterbitkan lebih dahulu terhadap peraturan daerah yang dibentuk. Penyelenggaraan pemerintahan daerah terdapat kondisi yang membutuhkan penanganan segera akan tetapi belum memiliki peraturan daerah sebagai dasar hukum sehingga dijumpai tindakan diskresi pemerintah daerah dengan pembentukan Peraturan Gubernur Sulawesi Tenggara Nomor 35 Tahun 2012 Tentang Kebutuhan dan Harga Enceran Tertinggi Pupuk Bersubsidi Untuk Sektor Pertanian Tahun 2013. Penelitian ini menggunakan penelitian hukum melalui pendekatan undang-undang dan konseptual hukum.

Adapun hasil penelitian ini adalah peraturan gubernur yang diterbitkan tanpa dasar peraturan daerah memiliki legitimasi hukum terbatas karena secara hierarki peraturan gubernur merupakan peraturan pelaksana dari peraturan daerah dalam konsep otonomi daerah, hal ini diatur dalam Undang-Undang Nomor 12 tahun 2011 tentang Pembentukan Peraturan Perundang-undangan dan Undang-Undang Nomor 23 tahun 2014 tentang Pemerintahan Daerah serta teori hukum yang relevan. Bahwa untuk menjamin kepastian hukum, keberlakuan hukum perlu dilakukan sinkronisasi secara vertikal. sinkronisasi vertikal dengan mengedepankan asas hukum Lex superior derogat legi inferior. Langkah sinkronisasi vertikal yaitu peraturan gubernur yang telah diterbitkan diperbaharui menjadi peraturan daerah setelah itu diterbitkan peraturan gubernur yang baru. Sinkronisasi hukum mempunyai peranan menjaga keselarasan dan mencegah tumpang tindihnya peraturan perundang-undangan. Terdapat rekomendasi antara lain perlu adanya peraturan tentang mekanisme sinkronisasi peraturan gubernur menjadi peraturan daerah dan Dewan Perwakilan Rakyat Daerah perlu meningkatkan kinerjanya dibidang legislasi agar mencegah terjadi penerbitan peraturan gubernur lebih dahulu daripada peraturan daerahnya.

Kata kunci: Peraturan Daerah; Peraturan Gubernur; Otonomi Daerah

\section{PENDAHULUAN}

Dalam penyelenggaraan otonomi daerah, peraturan daerah merupakan peraturan pokok sebagaimana tertuang dalam Pasal 17 Undang-Undang Nomor 23 Tahun 2014 tentang Pemerintahan Daerah yaitu daerah berhak menetapkan kebijakan daerah untuk menyelenggarakan urusan pemerintahan yang menjadi kewenangan daerah, ${ }^{1}$ selain itu dalam Pasal 236 ayat (1) Untuk menyelenggarakan otonomi daerah dan tugas pembatuan daerah membentuk Perda. Sebagai instrumen penyelenggaraan pemerintah daerah, peraturan daerah memiliki kedudukan hukum secara hierarki sebagaimana tertuang dalam Pasal 7 ayat (1) Undang-Undang Nomor 12 tahun 2011 tentang Pembentukan Peraturan Perundang-undangan mengenai jenis dan hierarki peraturan perundang-undangan terdiri atas: 1. Undang-Undang Dasar Negara Republik Indonesia Tahun 1945; 2. Ketetapan Majelis Permusyawaratan Rakyat;

1 Pasal 17 Undang-Undang Nomor 23 Tahun 2014 tentang Pemerintahan Daerah. 
3. Undang-Undang/Peraturan Pemerintah Pengganti Undang-Undang; 4. Peraturan Pemerintah; 5. Peraturan Presiden; 6. Peraturan daerah Provinsi; dan 7. Peraturan Daerah Kabupaten/Kota. Ayat (2) kekuatan hukum Peraturan Perundang-undangan sesuai dengan hierarki sebagaimana dimaksud ayat (1). Pada ayat (2) dinyatakan bahwa kekuatan hukum peraturan perundang-undangan sesuai dengan hierarki sebagaimana dimaksud pada ayat (1).

Peraturan daerah (Perda) sebagai peraturan pokok di daerah selanjutnya terdapat peraturan pelaksanaan yaitu peraturan gubernur atau peraturan kepala daerah (Perkada) yakni ditegaskan dalam Undang-Undang Nomor 12 Tahun 2011 Tentang Pembentukan Peraturan Perundang-undangan Pasal 8 ayat (1) yaitu: ${ }^{2}$

Jenis Peraturan Perundang-undangan selain sebagaimana dimaksud dalam Pasal 7 ayat (1) mencakup peraturan yang ditetapkan oleh Majelis Permusyawaratan Rakyat, Dewan Perwakilan Rakyat, Dewan Perwakilan Daerah, Mahkamah Agung, Mahkamah Konstitusi, Badan Pemeriksa Keuangan, Komisi Yudisial, Bank Indonesia, Menteri, badan, lembaga, atau komisi yang setingkat yang dibentuk dengan Undang-Undang atau Pemerintah atas perintah Undang-Undang, Dewan Perwakilan Rakyat Daerah Provinsi, Gubernur, Dewan Perwakilan Rakyat Daerah Kabupaten/Kota, Bupati/Walikota, Kepala Desa atau yang setingkat. Pada ayat (2) dua dinyatakan bahwa peraturan perundangundangan sebagaimana dimaksud pada ayat (1) diakui keberadaannya dan mempunyai kekuatan hukum mengikat sepanjang diperintahkan oleh Peraturan Perundangundangan yang lebih tinggi atau dibentuk berdasarkan kewenangan.

Kedudukan hukum peraturan daerah sebagai peraturan pokok didaerah dalam penyelenggaraan otonomi daerah dan tugas pembantuan memerlukan peraturan pelaksaannya yaitu peraturan kepala daerah atau peraturan gubernur ditingkat provinsi. Peraturan gubernur sebagai peraturan pelaksanaan dapat dibentuk ketika terdapat peraturan pokoknya didaerah yaitu peraturan daerah. Namun, dalam proses penyelenggaraan pemerintahan daerah Provinsi Sulawesi Tenggara terdapat kondisi yang membutuhkan penanganan segera akan tetapi belum memiliki peraturan daerah sebagai dasar hukum sehingga dijumpai tindakan diskresi yang dilakukan gubernur dengan menerbitkan Peraturan Gubernur Sulawesi Tenggara Nomor 35 Tahun 2012 Tentang Kebutuhan dan Harga Enceran Tertinggi (HET) Pupuk Bersubsidi Untuk Sektor Pertanian Tahun 2013. Hal ini didasari dengan pertimbangan bahwa peranan pupuk sangat penting dalam meningkatkan produktivitas dan produksi komoditas pertanian dalam rangka mewujudkan ketahanan pangan nasional.

Secara teoritis maupun normatif hal tersebut menyalahi kedudukan hukum peraturan perundang-undangan baik terhadap hierarki peraturan perundang-undangan sebagaimana

2 Pasal 8 ayat 1 Undang-Undang Nomor 12 tahun 2011 tentang Pembentukan Peraturan Perundang-undangan. 
diatur dalam Undang-Undang Nomor 12 tahun 2011 Tentang Pembentukan Peraturan Perundang-undangan dan Undang-Undang Nomor 23 tahun 2014 Tentang Pemerintahan Daerah. Beberapa kekhawatiran yang akan terjadi yaitu mengenai legalitas peraturan gubernur yang diterbitkan tanpa dasar peraturan daerah, semestinya dalam penyelenggaraan otonomi daerah peraturan daerah yang merupakan peraturan pokok penyelenggaraan otonomi daerah perlu dibentuk terlebih dahulu kemudian dibentuklah peraturan gubernur sebagai peraturan pelaksana atau mungkin peraturan gubernur sebagai peraturan pelaksana dapat mendahului peraturan pokok atau dasarnya. Selain itu, aspek lainnya adalah mengenai keberlakuan hukum peraturan gubernur sebagai peraturan pelaksana jika keharusan membentuk peraturan daerah harus dilakukan terutama pada aspek sinkronisasi hukum atas peraturan gubernur terhadap peraturan daerah. Berdasarkan latar belakang di atas maka penulis merumuskan dua rumusan masalah yakni Apakah peraturan gubernur yang diterbitkan tanpa dasar hukum peraturan daerah memiliki legitimasi hukum dan Bagaimana sinkronisasi hukum peraturan gubernur yang diterbitkan lebih dahulu terhadap peraturan daerah yang dibentuk.

\section{METODE PENELITIAN}

Tipe penelitian ini adalah tipe penelitian normatif. Adapun penelitian hukum (legal research) adalah menemukan kebenaran koherensi, yaitu adakah aturan hukum sesuai dengan norma hukum dan adakah norma yang berupa perintah atau larangan itu sesuai dengan prinsip hukum, serta apakah tindakan (act) seseorang sesuai dengan norma hukum atau prinsip hukum. Pendekatan yang digunakan dengan menggunakan pendekatan peraturan perundangundangan dan pendekatan konsep.

\section{ANALISIS DAN PEMBAHASAN}

\section{Legitimasi Hukum Peraturan Gubernur Tanpa Dasar Peraturan Daerah}

Undang-Undang Dasar Negara Republik Indonesia Tahun 1945 merupakan landasan yang kuat untuk menyelenggarakan otonomi daerah dengan memberikan kewenangan yang luas, nyata dan bertanggung jawab kepada daerah. ${ }^{3}$ Demokrasi didaerah merupakan bagian yang tidak terpisahkan dalam sistem hukum nasional, selain itu berpendapat Suharizal berpendapat

3 Kurniawan, Robi Cahyadi, Inovasi Kualitas Pelayanan Publik Pemerintah Daerah, Fiat Justisia Journal Of Law (3)569-86, 2016. hlm. 60. 
bahwa demokrasi di daerah merupakan prasyarat bagi munculnya demokrasi di tingkat nasional. ${ }^{4}$

Proses penyelenggaraan otonomi daerah dan tugas pembantuan, sebagaimana diatur dalam Pasal 1 ayat (2) Undang-Undang Nomor 23 Tahun 2014 Tentang Pemerintahan Daerah bahwa pemerintahan daerah adalah penyelenggaraan urusan pemerintahan oleh pemerintah daerah dan DPRD menurut asas otonomi dan tugas pembantuan dengan prinsip otonomi seluas-luasnya dalam sistem dan prinsip Negara Kesatuan Republik Indonesia sebagaimana dimaksud dalam Undang-Undang Dasar Negara Republik Indonesia Tahun 1945. 5 Peraturan daerah yang selanjutnya disebut Perda atau yang disebut dengan nama lain adalah Perda Provinsi dan Perda Kabupaten/Kota. ${ }^{6}$ Peraturan Kepala Daerah yang selanjutnya disebut Perkada adalah peraturan gubernur dan peraturan bupati/wali kota. ${ }^{7}$ Kedudukan Perda dalam Pasal 236 ayat (1) pula dinyatakan untuk menyelenggarakan otonomi daerah dan tugas pembantuan, daerah membentuk perda, pada ayat (2) Perda sebagaimana dimaksud pada ayat (1) dibentuk oleh DPRD dengan persetujuan bersama kepala daerah selain itu pula pada ayat (3) dinyatakan Perda sebagaimana yang dimaksud pada ayat (1) memuat materi muatan: a. Penyelenggaraan otonomi daerah dan tugas pembantuan; dan b. Penjabaran lebih lanjut ketentuan peraturan perundang-undangan yang lebih tinggi. ${ }^{8}$

Kedudukan peraturan gubernur diatur dengan Undang-Undang Nomor 23 Tahun 2014 tentang Pemerintahan Daerah dalam Pasal 246 pada Ayat (1) untuk melaksanakan Perda atau kuasa peraturan perundang-undangan, kepala daerah menetapkan Perkada. ${ }^{9}$ Selain itu dalam Pasal 247 perencanaan, penyusunan, dan penetapan Perkada berpedoman pada ketentuan peraturan perundang-undangan. ${ }^{10}$ Selanjutnya Pasal 250 Ayat (1) Perda dan Perkada sebagaimana dimaksud dalam pada ayat (1) dan ayat (3) dilarang bertentangan dengan ketentuan peraturan perundang-undangan yang lebih tinggi, kepentingan umum dan/atau kesusilaan. ${ }^{11}$

\footnotetext{
4 Suharizal, Penguatan Demokrasi Local Melalui Penghapusan Wakil Jabatan Kepala Daerah, Jurnal Konstitusi, vol. 7, No. 5 Oktober 2009, hlm. 95.

5 Pasal 1 ayat (2) Undang-Undang Nomor 23 tahun 2014 tentang Pemerintahan Daerah

Ibid., Pasal 1 ayat (25)

Ibid., Pasal 1 ayat (26)

Ibid., Pasal 236 ayat (1), (2), (3)

Ibid., Pasal 246 ayat (1)

Ibid., Pasal 247

1 Ibid., Pasal 250 ayat (1)
} 
Peraturan daerah pada hakikatnya adalah bagian yang tidak terpisah dari kesatuan hukum nasional.12 Dalam konteks tersebut, undang-undang sebagai hukum positif yang mengatur cara-cara dijalankannya kekuasaan. Hak-hak rakyat terepresentasikan dalam poin tersebut karena di dalam undang-undang terdapat kandungan pokok bahwa pembuatan dan pelaksanaan peraturan daerah semata untuk mendorong terciptanya kesejahteraan rakyat. Otonomi dan demokrasi merupakan satu kesatuan semangat sebagai bentuk pemerintahan yang menempatkan rakyat sebagai penentu yang utama dalam negara. ${ }^{13}$ Salah satu ciri utama demokrasi adalah keterikatan penguasa terhadap undang-undang dasar. ${ }^{14}$

Secara hierarki peraturan gubernur merupakan peraturan pelaksana secara yang kedudukannya diatur dalam Pasal 8 Ayat (1) Undang-Undang Nomor 12 tahun 2011 tentang Pembentukan Peraturan Perundang-undangan dan Pasal 8 Ayat (2)Undang-Undang Nomor 12 tahun 2011 tentang Pembentukan Peraturan Perundang-undangan, sebagai peraturan pelaksana dalam penyelenggaraan otonomi daerah, secara hierarki maka peraturan gubernur tidak boleh mendahului peraturan pokoknya yaitu peraturan daerah provinsi yang diatur dalam Pasal 7 Ayat (1) Undang-Undang Nomor 12 tahun 2011 tentang Pembentukan Peraturan Perundang-undangan dan Pasal 7 Ayat (1) Undang-Undang Nomor 12 tahun 2011 tentang Pembentukan Peraturan Perundang-undangan Pasal 7 Ayat (2) Undang-Undang Nomor 12 tahun 2011 tentang Pembentukan Peraturan Perundang-undangan, tanpa alasan yang diperbolehkan secara hukum.

Pengaturan yang mengatur pula tentang kedudukan peraturan kepala daerah yaitu dalam Peraturan Menteri dalam Negeri Nomor 80 tahun 2015 tentang Produk Hukum Daerah bahwa peraturan kepala daerah yang selanjutnya disebut Perkada adalah peraturan Gubernur dan/atau peraturan Bupati/Walikota. ${ }^{15}$ Selain itu pula kedudukan peraturan daerah diatur dalam peraturan menteri ini yaitu peraturan daerah provinsi atau nama lainnya dan peraturan daerah kabupaten/kota atau nama lainnya, yang selanjutnya disebut Perda, adalah peraturan perundang-undangan yang dibentuk oleh DPRD dengan persetujuan bersama kepala daerah. ${ }^{16}$

12 Didik Sukirno, Membela Desa dengan Desentralisasi dan Melawan Desa dengan Demokrasi, Jurnal Yustika, vol. 12 No. 2 Yursi, Jakarta, 2011, hlm. 60.

13 Didik Sukriono, Pembentukan dan Pengawasan Produk Hukum Daerah, Jurnal Hukum Adil Vol. 2 No, Fakultas Hukum Yarsi, Jakarta, 2011, hlm. 168.

14 Jutta Limbach, The Concept of the Supremacy of the Constitution, The Modern Law Review, Vol. 64 No. 1 Januari 2001, hlm. 3.

15 Pasal 1 ayat (5) Peraturan Menteri dalam Negeri Nomor 80 tahun 2015 tentang Produk Hukum Daerah

16 Ibid., Pasal 1 ayat (4) 
Kedudukan peraturan daerah dalam Peraturan Menteri Dalam Negeri Nomor 80 tahun 2015 Tentang Pembentukan Produk Hukum Daerah dalam Pasal 4 ayat (1) Perda sebagaimana dimaksud dalam pasal 3 huruf a terdiri atas: a. Perda provinsi; b. Perda kabupaten/kota selain itu pada ayat (2) Perda memuat materi muatan: a. Penyelenggaraan otonomi daerah dan tugas pembantuan; dan penjabaran lebih lanjut ketentuan peraturan perundang-undangan yang lebih tinggi. ${ }^{17}$ Lebih lanjut kedudukan peraturan gubernur pula diatur dalam Pasal 19 ayat (1) perencanaan penyusunan Perkada dan peraturan DPRD merupakan kewenangan dan disesuaikan kebutuhan lembaga, komisi, atau instansi masing-masing. (2) perencanaan penyusunan peraturan sebagaimana dimaksud pada ayat (1) disusun berdasarkan perintah peraturan perundang-undangan yang lebih tinggi atau berdasarkan kewenangan. ${ }^{18}$

Secara hierarki bahwa peraturan gubernur merupakan peraturan di bawah peraturan daerah hal ini sesuai pula dengan teori hierarki norma hukum dari Hans Kelsen ini diilhami oleh seorang muridnya yaitu Hans Nawiasky dengan teorinya teori jenjang norma bahwa, normanorma hukum itu berjenjang-jenjang dan berlapis-lapis dalam suatu hierarki (tata susunan), dalam arti suatu norma yang lebih rendah berlaku, bersumber, dan berdasar pada norma yang lebih tinggi, norma yang lebih tinggi berlaku, bersumber dan berdasar pada norma yang lebih tinggi lagi, demikian seterusnya sampai pada suatu norma yang tidak dapat ditelusuri lebih lanjut dan bersifat hipotesis dan fiktif yaitu norma dasar (Grundnorm). ${ }^{19}$

Adolf Merkl yang mengemukakan ${ }^{20}$ bahwa suatu norma hukum itu selalu mempunyai dua wajah (das doppelte Rechtsantlitz). Menurut Adolf Merkl suatu norma hukum itu ke atas ia bersumber dan berdasar pada norma yang di atasnya, tetapi ke bawah ia juga menjadi sumber dan menjadi dasar bagi norma hukum di bawahnya, sehingga suatu norma hukum itu mempunyai masa berlaku (rechtskracht) yang relatif, oleh karena masa berlakunya suatu norma hukum itu tergantung pada norma hukum yang berada di atasnya. Apabila norma hukum yang berada di atasnya dicabut atau dihapus, pada dasarnya norma-norma hukum yang berada di bawahnya akan tercabut atau terhapus pula. Menurut Ni'matul Huda, apabila peraturan Perundang-undangan yang lebih rendah bertentangan dengan di atasnya, maka peraturan tersebut dapat dituntut untuk dibatalkan atau batal demi hukum (van rechtswegenieting). ${ }^{21}$

\footnotetext{
Ibid., Pasal 4 ayat (1),(2)

Ibid., Pasal 19 ayat (1),(2)

19 Maria Farida Indrati Soeprapto, Ilmu Perundang-undangan (1) (Jenis, Fungsi, Materi Muatan), Yogyakarta: Kanisius, 2007, hlm. 41.

20 Ibid, hlm. 41-42.

21 Ni'matul Huda, Kedudukan Peraturan Daerah dalam Hierarki Peraturan Perundang-undangan, Jurnal Hukum Vol. 13 No.1 Januari 2006, hlm. 29.
} 
Sesuai teori yang dikemukakan para ahli tersebut jika dikaitkan dengan penerbitan peraturan gubernur yang diterbitkan terlebih dahulu dibandingkan peraturan daerahnya, hal ini menjadi permasalahan karena secara teori norma hukum yang dikemukakan Adolf Merk tersebut seharusnya peraturan gubernur tersebut dibentuk setelah adanya peraturan daerah sebagai peraturan yang lebih tinggi didaerah karena jika ini terjadi akan rusak tatanan hukum dalam hierarki peraturan perundang-undangan. Semestinya eksistensi pembentukan peraturan daerah tersebut dapat dilaksanakan karena menurut Bagir Manan menyatakan bahwa peraturan daerah adalah nama peraturan perundang-undangan tingkat daerah yang ditetapkan kepala daerah dengan persetujuan Dewan Perwakilan Rakyat. Kewenangan pemerintah daerah merupakan salah satu ciri yang menunjukkan bahwa pemerintah tingkat daerah tersebut adalah satuan pemerintahan otonom yang berhak mengatur dan mengurus rumah tangga daerahnya sendiri. ${ }^{22}$

C.F Strong yang mengatakan ${ }^{23}$ bahwa pemerintahan daerah adalah organisasi dimana diletakkan hak untuk melaksanakan kekuasaan berdaulat atau tertinggi. Pemerintahan dalam arti luas merupakan sesuatu yang lebih besar daripada suatu badan atau kelompok. Pemerintah daerah yang merupakan sub-sistem dari sistem penyelenggaraan pemerintahan nasional memiliki kewenangan untuk mengatur dan mengurus rumah tangganya sendiri. Kewenangan untuk mengatur dan mengurus rumah tangga ini mengandung tiga hal utama di dalamnya, ${ }^{24}$ yaitu: pertama, pemberian tugas dan wewenang untuk menyelesaikan suatu kewenangan yang sudah diserahkan kepada pemerintah daerah; kedua, pemberian kepercayaan dan wewenang untuk memikirkan, mengambil inisiatif dan menetapkan sendiri cara-cara penyelesaian tugas tersebut; dan ketiga, dalam upaya memikirkan, mengambil inisiatif dan mengambil keputusan tersebut mengikutsertakan masyarakat baik secara langsung maupun bersama DPRD. Pemberian peran yang lebih dominan kepada DPRD pada prinsipnya ditujukan pada pengembangan demokratisasi di daerah sehingga akuntabilitas penyelenggaraan pemerintahan daerah dapat terjamin. ${ }^{25}$ Selain itu untuk melaksanakan peraturan daerah memerlukan pula peraturan pelaksana yaitu peraturan kepala daerah selanjutnya disebut Perkada adalah peraturan gubernur dan bupati /wali kota. ${ }^{26}$

22 Amieroeddin Syahrif, Perundang-undangan Dasar, Jenis dan Teknik Membuatnya, Jakarta: Bina Aksara, 1987, hlm.71.

23 Fahmi Amrusi dalam Ni'matull Huda, Hukum Pemerintah Daerah, Bandung: Nusamedia, 2012, hlm. 28.

24 Setya Retnami, Makalah Sistem Pemerintahan Daerah di Indonesia, Jakarta: Kantor Menteri Negara Otonomi Daerah Republik Indonesia, 2001, hlm.8.

25 Hari Sabarno, Memandu Otonomi Daerah Menjaga Kesatuan Bangsa, Sinar Grafika, Jakarta, 2007, hlm. 6-7.

26 Op cit., Pasal 1 ayat (25) 
Teori klasik Trias Politika Montesquieau telah menancapkan teorisasi fundamental ketatanegaraan dengan mengemukakan organisasi kekuasaan sebuah negara atas kekuasaan Legislatif, Eksekutif dan Yudikatif. Kekuasaan Legislatif yang membentuk Peraturan, eksekutif mengeluarkan keputusan dan Putusan sebagai produk Yudikatif. Montesquieau memahamkan bahwa hubungan ketiga kekuasaan itu diletakkan terpisah, yang kemudian dikenal dalam konsepsi pemisahan kekuasaan. ${ }^{27}$ Kekuasaan harus tunduk kepada hukum dan hukum menjadi sarana pengendali, pengawas, dan pengontrol kekuasaan dari kemungkinan penyalahgunaan kekuasaan secara sewenang-wenang dalam pemberlakuan hukum. ${ }^{28}$

Pemberlakuan hukum mempunyai tujuan untuk membentuk legitimasi hukum, secara etimologi legitimasi berasal dari bahasa latin "lex" yang berarti hukum. Kata legitimasi identik dengan munculnya kata-kata seperti legalitas, legal dan legitimas. Jadi secara sederhana legitimasi adalah kesesuaian suatu tindakan perbuatan dengan hukum yang berlaku, atau peraturan yang ada, baik peraturan hukum formal, etis, adat istiadat maupun hukum kemasyarakatan yang sudah lama tercipta secara sah sedangkan legalitas adalah suatu tindakan yang legal atau resmi apabila dilakukan sesuai dengan hukum atau peraturan yang berlaku. Jadi legitimasi adalah kesesuaian dengan hukum yang berlaku. Legalitas menuntut agar kekuasaan ataupun wewenang dilaksanakan sesuai hukum yang berlaku. Karena itu legalitas merupakan salah satu pengujiannya pada suatu kekuasaan atau wewenang. ${ }^{29}$ Terhadap penyelenggaraan atau pelaksanaan pemerintahan.

Berdasarkan hasil wawancara peneliti dengan Muhammad Hasan, S.H. M.H KA SUBAG Evaluasi Peraturan Daerah Wilayah 1 Sekretariat Daerah Provinsi Sulawesi Tenggara mengemukakan bahwa:30

Batasan legitimasi hukum peraturan gubernur yang diterbitkan tanpa dasar peraturan daerah mempunyai legitimasi terbatas karena secara hierarki peraturan gubernur merupakan peraturan pelaksana didaerah berdasarkan peraturan daerah. Hal ini bertujuan untuk menjamin eksistensi penyelenggaraan otonomi daerah walaupun ada alasan bahwa, ada peraturan pemerintah pusat yang mengatur sehingga diterbitkan peraturan gubernur tersebut. Sehingga mencerminkan bahwa penyelenggaraan pemerintahan tidak hanya diselenggarakan dengan peraturan gubernur namun yang

27 Kamaruddin Jafar, Menguji 'Positive Legislature' Sebagai Kewenangan Mahkamah Konstitusi, Halu Oleo Law Review. Volume 1 Issue 2, September 2017. hlm. 248.

28 Guasman Tatawu, Hakekat Hukum Putusan Mahkamah Konstitusi terhadap Sengketa Pemilihan Kepala Daerah (Pilkada). Halu Oleo Law Review. Volume 1 Issue 2, September 2017. hlm.151-152.

29 Franz Magnis Suseno, Etika Politik Prinsip-prinsip Moral Dasar Kenegaraan Modern, Jakarta: Gramedia Pustaka Utama, 2015. hlm. 150.

30 Wawancara peneliti dengan Mohamad Hasan, Kasubag Evaluasi Peraturan Daerah Wilayah 1 Provinsi Sulawesi Tenggara Sekretariat Daerah Provinsi Sulawesi Tenggara pada tanggal 4 September 2019. Pkl. 15.00 WITA. 
terpenting perlu dijalankan dengan peraturan daerah sebagai peraturan pokok didaerah.

Batasan wewenang pembentukan peraturan perundang-undangan sesuai Pasal 15 Undang-Undang Nomor 30 Tahun 2014 tentang Administrasi Pemerintahan dinyatakan bahwa (1) Wewenang Badan dan/atau Pejabat Pemerintahan dibatasi oleh: a. masa atau tenggang waktu Wewenang; b. wilayah atau daerah berlakunya Wewenang; dan c. cakupan bidang atau materi Wewenang. Berdasarkan materi peraturan gubernur merupakan peraturan pelaksana dari peraturan daerah secara hierarki peraturan perundang-undangan sedangkan berdasarkan masa atau tenggang waktu peraturan gubernur tidak mempunyai tenggang waktu batasan berlakunya hanya saja mempunyai batasan ketika ada penghapusan peraturan gubernur tersebut dan diterbitkan peraturan yang baru, selain itu pula pada wilayah berlakunya hanya pada daerah yang diatur dalam peraturan gubernur, bukan mengatur pada wilayah otoritas daerah yang lain.

Dalam penyelenggaraan otonomi daerah, penerbitan Peraturan Gubernur Sulawesi Tenggara Nomor 35 Tahun 2012 Tentang Kebutuhan dan Harga Enceran Tertinggi (HET) Pupuk Bersubsidi Untuk Sektor Pertanian Tahun 2013 belum memiliki dasar hukum peraturan daerah, padahal peraturan gubernur perlu dibentuk atas aturan pokok didaerah yaitu peraturan daerah provinsi secara hierarki. Permasalahannya yaitu ketika peraturan gubernur bertentangan dengan peraturan daerah yang dibuat Dewan Perwakilan Rakyat Daerah Provinsi dengan persetujuan kepala daerah akan menyulitkan untuk mengontrol dan mengawasinya secara jelas dan peraturan daerah pun bisa menjadi alat uji peraturan gubernur sehingga ketika peraturan gubernur lebih dahulu diterbitkan karena alasan diskresi itu diperbolehkan sesuai yang diatur dalam Undang-Undang Nomor 30 tahun 2014 tentang Administrasi Pemerintahan dinyatakan bahwa diskresi adalah keputusan dan/atau tindakan yang ditetapkan dan/atau dilakukan oleh pejabat pemerintahan untuk mengatasi persoalan konkret yang dihadapi dalam penyelenggaraan pemerintahan dalam hal peraturan perundang-undangan yang memberikan pilihan, tidak mengatur, tidak lengkap atau tidak jelas, dan/atau adanya stagnasi pemerintahan. ${ }^{31}$ Namun, hal ini hanya mempunyai legitimasi hukum terbatas karena secara hierarki peraturan gubernur merupakan peraturan pelaksana dari peraturan daerah dan otoritas pembentukan peraturan didaerah dilakukan oleh Dewan Perwakilan Rakyat Daerah dengan Persetujuan Kepala Daerah dengan menghasilkan produk hukum yaitu peraturan

31 Pasal 1 ayat 9 Undang-Undang Nomor 30 tahun 2014 tentang Administrasi Pemerintahan 
daerah sedangkan peraturan gubernur dilakukan sepihak oleh gubernur dan kecenderungan terjadi abuse of power (penyalahgunaan wewenang) yang dilakukan gubernur. Selain itu pula peraturan gubernur yang diterbitkan tanpa peraturan daerah tersebut harus memenuhi pula unsur asas-asas umum pemerintahan yang baik (AUPB). AUPB yang dimaksud dalam undangundang ini meliputi asas: a. kepastian hukum; b. kemanfaatan; c. ketidakberpihakan; d. kecermatan; e. tidak menyalahgunakan kewenangan; f. keterbukaan; g. kepentingan umum; dan h. pelayanan yang baik. ${ }^{32}$ AUPB merupakan pelaksanaan pemerintahan yang baik oleh penyelenggara negara yang taat asas hukum dalam proses penyelenggaraan pemerintahan.

\section{Sinkronisasi Hukum Peraturan Gubernur Yang Dibentuk Terlebih Dahulu Terhadap Peraturan Daerah}

Sinkronisasi hukum adalah penyelarasan dan penyerasian berbagai peraturan perundangundangan yang terkait dengan peraturan perundang-undangan yang telah ada dan yang sedang disusun yang mengatur suatu bidang tertentu. Maksud dari kegiatan sinkronisasi adalah agar substansi yang diatur dalam produk perundang-undangan tidak tumpang tindih, saling melengkapi (suplementer), saling terkait, dan semakin rendah jenis pengaturannya maka semakin detail dan operasional materi muatannya. Adapun tujuan dari kegiatan sinkronisasi adalah untuk mewujudkan landasan pengaturan suatu bidang tertentu yang dapat memberikan kepastian hukum yang memadai bagi penyelenggaraan bidang tertentu secara efisien dan efektif. ${ }^{33}$

Endang Sumiarni berpendapat, sinkronisasi adalah dengan melihat kesesuaian atau keselarasan peraturan perundang-undangan secara vertikal berdasarkan sistematisasi hukum positif yaitu antara perundang-undangan yang lebih tinggi dengan peraturan perundangundangan yang lebih rendah. Sinkronisasi peraturan perundang-undangan sering menimbulkan pertentangan mengenai peraturan perundang-undangan yang lebih tepat digunakan untuk kasus tertentu. Oleh karena itu para pembentuk peraturan perundangundangan perlu memperhatikan asas-asas berlakunya peraturan perundang-undangan. Peter Mahmud Marzuki, terkait sinkronisasi peraturan perundang-undangan terdapat asas lex superiori derogat legi inferiori yang menjelaskan bahwa apabila terjadi pertentangan antara

32 Pasal 10 Undang-Undang Nomor 30 tahun 2014 tentang Administrasi Pemerintahan

33 Inche Sayuna, Harmonisasi dan Sinkronisasi Hukum Surat Kuasa Membebankan Hak Tanggungan (SKMHT) Ditinjau Dari Otentisitas Akta Menurut Undang-Undang Nomor 2 Tahun 2014 tentang Perubahan Atas UndangUndang Nomor 30 Tahun 2004 tentang Jabatan Notaris, Tesis, Surakarta: Universitas Sebelas Maret, hlm.17 
peraturan perundang-undangan yang secara hierarki lebih rendah, maka peraturan perundangundangan yang lebih rendah itu harus disisihkan. ${ }^{34}$

Sinkronisasi juga jika dikaitkan dengan pengharmonisasian peraturan didaerah diatur dalam Peraturan Menteri Hukum dan Hak Asasi Manusia Republik Indonesia Nomor 22 Tahun 2018 Tentang Pengharmonisasian Rancangan Peraturan Perundang-undangan yang Dibentuk Di Daerah Oleh Perancang Peraturan Perundang-Undangan menjadi acuan untuk mengharmonisasikan peraturan didaerah pada pasal 1 ayat (2) dinyatakan bahwa pengharmonisasian rancangan peraturan perundang-undangan yang selanjutnya disebut pengharmonisasian adalah proses penyelarasan substansi rancangan peraturan perundangundangan dan teknik penyusunan peraturan perundang-undangan, sehingga menjadi peraturan perundang-undangan yang merupakan satu kesatuan yang utuh dalam kerangka sistem hukum nasional. ${ }^{35}$ Pengharmonisasian rancangan peraturan perundang-undangan yang dibentuk di daerah oleh perancang sebagaimana dimaksud dalam Pasal 2 ayat (1) meliputi: a. rancangan peraturan daerah Provinsi; b. rancangan peraturan daerah kabupaten/kota; c. rancangan peraturan gubernur; d. rancangan peraturan bupati/wali Kota; e. rancangan peraturan desa atau yang setingkat; dan f. rancangan peraturan kepala desa atau rancangan peraturan yang setingkat. ${ }^{36}$

Menurut L.M. Gandhi, dalam "Sinkronisasi Hukum Menuju Hukum Responsif" menyebutkan bahwa;

"Sinkronisasi dalam hukum adalah mencakup penyesuaian peraturan perundangundangan, keputusan pemerintah, keputusan hakim, sistem hukum dan asas-asas hukum dengan tujuan peningkatan kesatuan hukum, kepastian hukum, keadilan dan kesebandingan, kegunaan dan kejelasan hukum, tanpa mengaburkan dan mengorbankan pluralisme hukum."37

Perbedaan penafsiran atau disinkronisasi peraturan perundang-undangan akan mengakibatkan munculnya permasalahan di dalam implementasinya. Ada 6 (enam) faktor yang menyebabkan disinkronisasi sebagai berikut: 38

\footnotetext{
34 Ibid., hlm.18

35 Pasal 1 ayat 2 Peraturan Menteri Hukum dan Hak Asasi Manusia Republik Indonesia Nomor 22 Tahun 2018 Tentang Pengharmonisasian Rancangan Peraturan Perundang-Undangan Yang Dibentuk Di Daerah Oleh Perancang Peraturan Perundang-Undangan.

36 Ibid., Pasal 3

37 L.M. Gandhi, "Harmonisasi Hukum Menuju Hukum Yang Responsif”, Makalah, yang disampaikan pada Pidato Pengukuhan Guru Besar Tetap FH-UI, 1995.

38 AA. Oka Mahendra, Harmonisasi Peraturan Perundang-undangan, Departemen Hukum dan HAM, http://www.djpp.depkumham.go.id/htn-dan-puu/421-harmonisasi-peraturan-perundang-undangan. html, diakses tanggal 13 Agustus 2019.
} 
a. Pembentukan dilakukan oleh lembaga yang berbeda dan sering dalam kurun waktu yang berbeda;

b. Pejabat yang berwenang untuk membentuk peraturan perundang-undangan berganti-ganti baik karena dibatasi oleh masa jabatan, alih tugas atau penggantian;

c. Pendekatan sektoral dalam pembentukan peraturan perundang-undangan lebih kuat dibanding pendekatan sistem;

d. Lemahnya koordinasi dalam proses pembentukan peraturan perundang-undangan yang melibatkan berbagai instansi dan disiplin hukum;

e. Akses masyarakat untuk berpartisipasi dalam proses pembentukan peraturan perundang-undangan masih terbatas;

f. Belum mantapnya cara dan metode yang pasti, baku dan standar yang mengikat semua lembaga yang berwenang membuat peraturan perundang-undangan.

Peraturan perundang-undangan perbedaan penafsiran dalam pelaksanaannya; timbulnya ketidakpastian hukum; peraturan perundang-undangan tidak terlaksana secara efektif dan efisien, serta disfungsi hukum, artinya hukum tidak dapat berfungsi memberikan pedoman berperilaku kepada masyarakat, pengendalian sosial, penyelesaian sengketa dan sebagai sarana perubahan sosial secara tertib dan teratur. ${ }^{39}$

Berdasarkan wawasan dan pokok-pokok pikiran atau pandangan doktrin hukum tersebut akan melahirkan konsep sinkronisasi sistem hukum, yang akan mendasari perumusan perencanaan hukum (legislation planning) dan proses pembentukan hukum (law making process) melalui peraturan perundang-undangan. Pada akhirnya melalui penerapan hukum (law enforcement) diharapkan akan tercipta peraturan perundang-undangan nasional yang harmonis, dalam arti selaras, serasi, seimbang, terintegrasi dan konsisten, serta taat asas, sebagai keluaran (produk) dari proses harmonisasi hukum. Penilaian atau evaluasi terhadap hasil yang dicapai atau produk dari harmonisasi hukum tersebut, baik yang berkaitan dengan pengaruhnya terhadap keberadaan sistem hukum nasional yang sedang berjalan (existing legal system) yang mencakup unsur-unsur substansi hukum, struktur hukum beserta kelembagaannya dan budaya hukum, selanjutnya akan menimbulkan suatu wawasan atau pandangan hukum baru yang akan memperbarui pula wawasan dan perumusan garis kebijakan hukum (legal policy) ke depan. ${ }^{40}$

Dalam kerangka demikian secara berkelanjutan, sinkronisasi hukum akan terusmenerus berkembang di dalam satu kerangka sistem hukum nasional dengan pendekatan sistem dan pandangan konseptual. Perumusan konsep langkah sistemis sinkronisasi hukum,

39 Ibid., hlm. 35

40 Nonet, Philip dan Selznick, Law Society In Transition, Toward Responsive Law, Harper: Torchbooks, 1978, hlm. 30. 
sebagai kerangka umum yang memberikan pedoman dalam penyesuaian asas dan sistem hukum pada proses pembentukan peraturan perundang-undangan, dalam rangka mewujudkan peraturan perundang-undangan nasional yang harmonis, terintegrasi, konsisten dan taat asas. ${ }^{41}$ Dalam perspektif demikian masalah kepastian hukum akan dirasakan sebagai kebutuhan yang hanya dapat terwujud melalui sinkronisasi sistem hukum. ${ }^{42}$

Penyelenggaraan pemerintahan daerah hal yang paling menjadi perhatian bahwa Peraturan gubernur diterbitkan lebih dahulu dibandingkan peraturan daerah padahal pada dasarnya peraturan gubernur merupakan peraturan pelaksana peraturan daerah sehingga diperlukan upaya sinkronisasi hukum. Proses sinkronisasi Peraturan Gubernur Sulawesi Tenggara Nomor 35 Tahun 2012 Tentang Kebutuhan dan Harga Enceran Tertinggi (HET) Pupuk Bersubsidi Untuk Sektor Pertanian Tahun 2013 terhadap peraturan daerah sangat diperlukan karena mengingat peraturan gubernur tersebut lebih dahulu diterbitkan dibandingkan peraturan daerahnya, maka perlu dilakukan sinkronisasi hukum. Sinkronisasi hukum adalah upaya atau proses yang hendak mengatasi batasan-batasan perbedaan, hal-hal yang bertentangan dan kejanggalan dalam hukum. Upaya atau proses untuk merealisasi keselarasan, kesesuaian, keserasian, kecocokan, keseimbangan di antara norma-norma hukum di dalam peraturan perundang-undangan sebagai sistem hukum dalam satu kesatuan kerangka sistem hukum nasional. 43

Secara sederhana penulis membentuk proses sinkronisasi dalam bentuk bagan sebagai berikut:

Bagan sinkronisasi peraturan gubernur terhadap peraturan daerah:

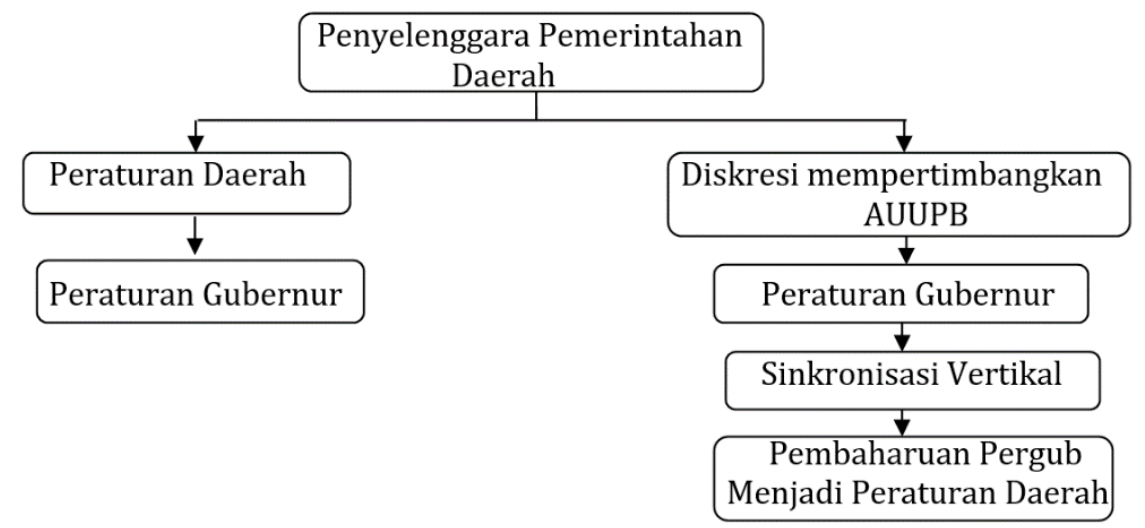

41 Pound, Roscoe, An Intoduction to the Philosophy of Law, New Heaven: Yale University Press, 1954, hlm.70.

42 Kusnu Goesniadhie, Harmonisasi Hukum Dalam Persfektif Perundang-undangan; Lex Specialis Suatu Masalah, Surabaya: JP Books, 2006, hlm.100.

43 Yordan Gunawan, 2012, Pentingnya Harmonisasi Hukum Negara dan Hukum Islam, Yogyakarta: UMY Press, hlm. 24. 
Pada proses sinkronisasi peraturan gubernur terhadap peraturan daerah dilakukan agar menjamin eksistensi otonomi daerah dalam hal penyelenggaraan otonomi daerah dan tugas pembantuan sehingga hal ini diatur dalam Undang-Undang Nomor 23 tahun 2014 tentang Pemerintahan Daerah dinyatakan bahwa, untuk menyelenggarakan otonomi daerah dan tugas pembantuan, daerah membentuk Perda. ${ }^{44}$ Selanjutnya dibentuk peraturan gubernur namun ada fakta hukum hal ini terjadi lebih dahulu diterbitkan peraturan gubernur daripada peraturan daerah. Secara hierarki peraturan perundang-undangan mengamanatkan bahwa kekuatan hukum mengikat peraturan perundang-undangan harus dibentuk secara hierarki peraturan perundang-undangan.

Penerbitan peraturan gubernur lebih dahulu diterbitkan karena adanya alasan diskresi sebagaimana diatur dalam Undang-Undang Nomor 30 tahun 2014 tentang Administrasi Pemerintahan dinyatakan bahwa diskresi adalah keputusan dan/atau tindakan yang ditetapkan dan/atau dilakukan oleh pejabat pemerintahan untuk mengatasi persoalan konkret yang dihadapi dalam penyelenggaraan pemerintahan dalam hal peraturan perundang-undangan yang memberikan pilihan, tidak mengatur, tidak lengkap atau tidak jelas, dan/atau adanya stagnasi pemerintahan. 45

Berdasarkan hasil wawancara Peneliti dengan Muhammad Hasan, S.H., M.H. KASUBAG evaluasi Peraturan Daerah wilayah 1 Provinsi Sulawesi Tenggara Sekretariat Daerah Provinsi Sulawesi Tenggara mengatakan bahwa:

Peraturan gubernur yang diterbitkan terlebih dahulu terhadap peraturan daerah yang dibentuk kemudian mempunyai legitimasi hukum sementara dan terbatas karena secara hierarki peraturan gubernur merupakan peraturan pelaksana dari peraturan daerah dan peraturan gubernur tersebut bersifat tetap ketika sudah diperbaharui untuk disinkronisasikan menjadi Perda sebagai peraturan pokoknya lalu diterbitkan kembali peraturan gubernur tersebut sebagai peraturan pelaksana didaerah. selain itu pula peraturan gubernur yang diterbitkan tanpa peraturan daerah tersebut harus memenuhi pula unsur asas-asas umum pemerintahan yang baik (AUPB). ${ }^{46}$

Pengaturan AUPB yang dimaksud dalam Undang-Undang ini meliputi asas: a. kepastian hukum; b. kemanfaatan; c. ketidakberpihakan; d. kecermatan; e. tidak menyalahgunakan kewenangan; f. keterbukaan; g. kepentingan umum; dan h. pelayanan yang baik. ${ }^{47}$ Penerbitan

44 Pasal 236 ayat 1 Undang-Undang Nomor 23 tahun 2014 tentang Pemerintahan Daerah

45 Pasal 1 ayat 9 Undang-Undang Nomor 30 tahun 2014 tentang Administrasi Pemerintahan

46 Wawancara peneliti dengan Mohamad Hasan, S.H., M.H. KASUBAG evaluasi Peraturan Daerah wilayah 1 Provinsi Sulawesi Tenggara Sekretariat Daerah Provinsi Sulawesi Tenggara pada tanggal 4 September 2019. Pkl. 15.00 WITA.

47 Pasal 10 Undang-Undang Nomor 30 tahun 2014 tentang Administrasi Pemerintahan 
peraturan gubernur yang telah diterbitkan dan berdasarkan asas-asas umum pemerintahan yang baik (AUPB) tidak cukup namun perlu dilakukan sinkronisasi atau harmonisasi menurut Isna Wahyudi bahwa, sinkronisasi peraturan perundang-undangan dapat dibagi menjadi dua jenis, yaitu:

Sinkronisasi vertikal dan horizontal. Pembagian tersebut didasarkan pada kedudukan antara satu peraturan perundang-undangan dengan peraturan perundang-undangan yang lain. sinkronisasi vertikal adalah sinkronisasi antara peraturan perundangundangan dengan peraturan perundang-undangan lain dalam hierarki yang berbeda, sinkronisasi ini mengandung asas lex superior derogat legi inferior. Sementara sinkronisasi horizontal adalah sinkronisasi antara peraturan perundang-undangan dengan peraturan perundang-undangan lain dalam hierarki yang sama. Pemaknaan, sinkronisasi ini berdasar pada asas hukum lex posteriori derogat legi priori. ${ }^{48}$

Berdasarkan pendapat Isna Wahyudi tersebut mengenai sinkronisasi peraturan perundang-undangan, jika dikaitkan dengan peraturan gubernur yang diterbitkan lebih dahulu terhadap peraturan daerah yang dibentuk kemudian hal ini secara hierarki bertentangan maka cara sinkronisasi dengan sinkronisasi vertikal dalam pemaknaan asas hukum lex superior derogat legi inferior sehingga peraturan gubernur merupakan peraturan di bawah peraturan daerah secara hierarki maka substansi peraturan gubernur tersebut diperbaharui keperaturan daerah setelah itu diterbitkan kembali Pergub yang baru karena pertimbangan peraturan gubernur sebagai peraturan pelaksana didaerah, karena kekhawatiran yang terjadi yaitu ketika tidak diharmonisasi akan terjadi yang namanya disharmonisasi hukum serta akan terjadi abuse of power atau penyalahgunaan wewenang kepala daerah karena bagian kewenangan membentuk Pergub dengan alasan keadaan mendesak implikasi yang terjadi adalah akan lebih banyak Pergub dibandingkan Perda. Selain itu pula otoritas pembentuk peraturan didaerah yaitu Dewan Perwakilan Rakyat Daerah sebagai representatif rakyat karena bagian dari proses demokrasi didaerah sedangkan pemerintah daerah melaksanakan aturan tersebut dengan menerbitkan peraturan gubernur sebagai peraturan pelaksana. Jadi hukum yang diproduksi oleh para wakil rakyat harus menggambar kedaulatan rakyat, bukan pribadi, kelompok atau bahkan partai. ${ }^{49}$

48 Isna Wahyudi, Harmonisasi Hukum dalam Penyelesaian Sengketa Ekonomi Syariah Melalui Peraturan Mahkamah Agung (Perma), http://s3.amazonaws.com/academia.edu.documents/37422223/Harmonisasi_ Hukum_dalam_Penyelesaian_Sengketa_Ekonomi_Syariah.pdf?, diakses pada hari Minggu 1 September 2019.

49 Firdaus, Membangun Hukum Indonesia Yang Berwawasan Nilai-Nilai Pancasila, Jurnal Konstitusi, Volume IV No.1, Juni 2011, hlm. 121. 


\section{KESIMPULAN}

Berdasarkan pada uraian pembahasan yang telah dikemukakan di atas, penulis dapat simpulkan yaitu:

1. Peraturan gubernur secara hierarki dalam Undang-Undang Nomor 12 tahun 2011 tentang Pembentukan Peraturan Perundang-undangan merupakan peraturan di bawah peraturan daerah dan peraturan gubernur merupakan peraturan pelaksana yang kedudukannya diatur dalam Pasal 246 Undang-Undang Nomor 23 tahun 2014 tentang Pemerintahan Daerah, sebagai peraturan pelaksana dari peraturan daerah, secara hierarki maka peraturan gubernur tidak boleh mendahului peraturan pokoknya yaitu peraturan daerah provinsi, jika terjadi karena alasan diskresi peraturan gubernur tersebut mempunyai legitimasi hukum terbatas karena secara hierarki peraturan gubernur sebagai peraturan pelaksana dari peraturan daerah. Selain itu otoritas pembentukan peraturan daerah Provinsi dibentuk oleh DPRD Provinsi bersama kepala daerah sedangkan pembentukan peraturan gubernur dilakukan sepihak oleh gubernur saja.

2. Sinkronisasi Peraturan Gubernur Sulawesi Tenggara Nomor 35 Tahun 2012 Tentang Kebutuhan dan Harga Enceran Tertinggi (HET) Pupuk Bersubsidi Untuk Sektor Pertanian Tahun 2013 yang diterbitkan lebih dahulu terhadap peraturan daerah yang dibentuk kemudian ini perlu diperbaharui substansinya menjadi Perda dan diterbitkan kembali menjadi Pergub yang baru. Langkah ini dilakukan untuk menjamin sinkronisasi sistem hukum nasional dengan cara sinkronisasi vertikal maupun sinkronisasi horizontal.

\section{Daftar Pustaka}

\section{Buku}

Goesniadhie, Kusnu, Harmonisasi Hukum Dalam Persfektif Perundang-undangan; Lex Specialis Suatu Masalah, Surabaya: JP Books, 2006.

Gunawan, Yordan, Pentingnya Harmonisasi Hukum Negara dan Hukum Islam, UMY Yogyakarta:

Press, 2012.

Ni'matull, Huda, Hukum Pemerintah Daerah, Bandung: Nusamedia, 2012.

Nonet, Philip dan Selznick, Law Society In Transition, Toward Responsive Law, Harper: Torchbooks, 1978. 
Pound, Roscoe, An Intoduction to the Philosophy of Law, New Heaven: Yale University Press, 1954.

Sabarno, Hari, Memandu Otonomi Daerah Menjaga Kesatuan Bangsa, Jakarta: Sinar Grafika, 2007.

Soeprapto, Maria Farida Indrati, Ilmu Perundang-undangan (1) (Jenis, Fungsi, Materi Muatan), Yogyakarta: Kanisius, 2007.

Suseno, Franz Magnis, Etika Politik Prinsip-prinsip Moral Dasar Kenegaraan Modern, Jakarta: Gramedia Pustaka Utama, 2015.

Syahrif, Amieroeddin, Perundang-undangan Dasar, Jenis dan Teknik Membuatnya, Jakarta: Bina Aksara, 1987.

Retnami, Setya, Makalah Sistem Pemerintahan Daerah di Indonesia, Jakarta: Kantor Menteri Negara Otonomi Daerah Republik Indonesia, 2001.

\section{Peraturan Perundang-undangan}

Undang-Undang Nomor 12 tahun 2011 tentang Pembentukan Peraturan Perundang-undangan. Undang-Undang Nomor 23 Tahun 2014 tentang Pemerintahan Daerah.

Undang-Undang Nomor 30 tahun 2014 tentang Administrasi Pemerintahan.

Peraturan Menteri dalam Negeri Nomor 80 tahun 2015 tentang Produk Hukum Daerah.

Peraturan Menteri Hukum dan Hak Asasi Manusia Republik Indonesia Nomor 22 Tahun 2018 Tentang Pengharmonisasian Rancangan Peraturan Perundang-Undangan Yang Dibentuk Di Daerah Oleh Perancang Peraturan Perundang-Undangan.

\section{E-Jurnal dan situs internet}

Firdaus, Membangun Hukum Indonesia Yang Berwawasan Nilai-Nilai Pancasila, Jurnal Konstitusi, Volume IV No.1, Juni 2011.

Gandhi, L.M., "Harmonisasi Hukum Menuju Hukum Yang Responsif”, Makalah, yang disampaikan pada Pidato Pengukuhan Guru Besar Tetap FH-UI, 1995.

Huda, Ni'matul, Kedudukan Peraturan Daerah dalam Hierarki Peraturan Perundang-undangan', Jurnal Hukum, Vol. 13 No.1 Januari 2006.

Jafar, Kamaruddin, Menguji 'positive Legislature' sebagai Kewenangan Mahkamah Konstitusi, Halu Oleo Law Review. Volume 1 Issue 2, September 2017.

Kurniawan, Robi Cahyadi, Inovasi Kualitas Pelayanan Publik Pemerintah Daerah, Fiat Justisia Journal Of Law (3) 569-86, 2016. 
Limbach, Jutta, The Concept of the Supremacy of the Constitution, The Modern Law Review, Vol. 64 No. 1 Januari 2001.

Sayuna, Inche, Harmonisasi dan Sinkronisasi Hukum Surat Kuasa Membebankan Hak Tanggungan (SKMHT) Ditinjau Dari Otentisitas Akta Menurut Undang-Undang Nomor 2 Tahun 2014 tentang Perubahan Atas Undang-Undang Nomor 30 Tahun 2004 tentang Jabatan Notaris, Tesis, Surakarta: Universitas Sebelas Maret.

Suharizal, Penguatan Demokrasi Local Melalui Penghapusan Wakil Jabatan Kepala Daerah, Jurnal Konstitusi, Vol. 7, No. 5 Oktober 2009.

Sukirno, Didik, Membela Desa dengan Desentralisasi dan Melawan Desa dengan Demokrasi, Jurnal Yustika, Vol. 12 No. 2 Yursi, Jakarta, 2011.

Sukriono, Didik, "Pembentukan dan Pengawasan Produk Hukum Daerah", Jurnal Hukum Adil Vol. 2 No, Fakultas Hukum Yarsi, Jakarta, 2011.

Tatawu, Guasman, Hakekat Hukum Putusan Mahkamah Konstitusi terhadap Sengketa Pemilihan Kepala Daerah (Pilkada). Halu Oleo Law Review. Volume 1 Issue 2, September 2017.

\section{Situs internet}

Mahendra, AA. Oka, Harmonisasi Peraturan Perundang-undangan, http://www. djpp.depkumham.go.id/htn-dan-puu/421-harmonisasi-peraturan-perundangundangan. html diakses tanggal 13 Agustus 2019.

Wahyudi, Isna, Harmonisasi Hukum dalam Penyelesaian Sengketa Ekonomi Syariah Melalui Peraturan Mahkamah Agung (Perma), http://s3.amazonaws.com/academia.edu. documents/37422223/Harmonisasi_Hukum_dalam_Penyelesaian_Sengketa_Ekonomi_S yariah.pdf?, diakses pada hari Minggu 1 September 2019. 